Eletronic M agazine: Time - Techinique - Territorry, V.5, N.2 (2014), 55:76 ISSN: 2177-4366

DOI: https://doi.org/10.26512/ciga.v5i2.15401

\title{
GEOLAW AND THE GEOGRAPHIC-CARTOGRAPHIC CONSTRUCTION AS INSTRUMENT OF PUBLIC POLITICS IN THE ELECTRICITY SECTOR
}

\author{
Luiz Antonio Ugeda Sanches \\ Doctoral Student in Geography at the University of Brasília (UnB). Master in \\ Geography and in Law at the Catholic University of São Paulo (PUC/SP). \\ Email: 1as@geodireito.com \\ Tradução para o Português: Cleison Leite Ferreira
}

\begin{abstract}
The present study shows the interdisciplinarity between Geosciences and Law as an inseparable element of the construction of public politics that presuppose the use of geotechnologies. There is a demonstration of how this interdisciplinarity is treated by the law throughout the history of Brazil, as well as its application in the electricity sector, especially in the monitoring and control process of the Agência Nacional de Energia Elétrica (ANEEL).
\end{abstract}

Keywords: Geodireito, Public Politics, Electric Power, Geographic Information System

RESUMO: O presente estudo mostra a interdisciplinaridade entre Geociências e Direito como elemento indissociável da construção de políticas públicas que pressupõem o uso das geotecnologias. Há a demonstração de como esta interdisciplinaridade é tratada pela legislação ao longo da história do Brasil, bem como sua aplicação no setor elétrico, principalmente no processo regulatório e fiscalizatório da Agência Nacional de Energia Elétrica - Aneel.

Palavras-chave: Geodireito, Políticas Públicas, Energia Elétrica, Sistema de Informações Geográficas

RÉSUMÉ: La présente étude montre l'interdisciplinarité entre les sciences de la terre et le droit comme un élément indissociable de la construction des politiques publiques qui prennent en charge l'utilisation de la géotechnique. Il s'agit d'une démonstration de la façon dont cette interdisciplinarité est traitée par la loi tout au long de l'histoire du Brésil, ainsi que son application dans le secteur de l'énergie, en particulier dans le processus de l'Agence nationale de l'électricité surveillance et de contrôle - ANEEL. 
Mots-clés: Geodireito, les politiques publiques, de l'énergie, systèmes d'information géographique

\section{Introduction}

Imagine a sports field present in any club or condo middle class in Brazil. In this space there are overlapping lines demarcating the rules of the game of soccer, basketball, volleyball, handball and tennis. There are a post and a basket in each of the two ends of the court. Athletes begin to play all the sports that have their lines projected on the floor at the same time and submitted to their respective arbitrators, each with distinct powers to mediate the players.

The result of this catharsis would be at least curious. If each of the athletes tried to enforce their sport at the expense of others, valuing their respective sports by the high art of its rules or by the simple use of force, they would be shocked on the court, the balls would change, there would be mixing rules, and even the colors of the uniform. In addition, the results would be highly predictable: injured players, errors in counting points, higher possibility of irregularities, finally, total impracticality of concomitant practice of sports in the same space.

The example of this poorly stitched parable, if transported to the Brazilian geo-legal reality, would still be simple. This is because Brazil, this huge space of conflicts of interest, has numerous delimitations in its territory (surface, underground, sea, air and spatial), which can be geographic (international, national, regional and local), legal (Federal, the States, the Federal District and Municipalities)and sectoral (energy, sanitation, transports, telecommunications, environmental, among others).

So the Geodireito understood as the technique of employing the formal geoscientific knowledge and materially in law finds constitutional support in the Union's competences to organize and maintain the official statistical services, geography, geology and cartography at the national level (Article 21, XV, CF), being the only one to legislate about statistical, cartographic and geological system (Article 22, XVIII, CF) and being allowed to articulate its action in the same geo-economic complex to reduce regional inequalities (Article 43, CF).

This study aims to demonstrate the interdisciplinary attribute between Science and Law as an inseparable element of the construction of public politics that 
presuppose geotechnologies. There is a pointing of how this interdisciplinarity is treated by the law throughout the history of Brazil, as well as its application in the electricity sector, especially in the monitoring and control process of the Agência Nacional de Energia Elétrica - ANEEL.

\section{Geolaw and interdisciplinarity between Geography and Law}

The space and the norm, sheltered their different senses, are the product of social and political relations of a given society. The "Law \& Geography" is a school of legal thought discussed mainly in the North American West and in England which had its first manifestations in the 1980s, when the Anglo-Saxon geographers began to question how and why the norm interferes in Space. In the same period, jurists have also initiated studies about Law and Economics ("Law \& Economics", which in Brazil would be studied by the Economic Administrative Law), critical legal theory, and Law and Literature. ${ }^{1}$

In the next ten years there has been a large volume of publications that explored the relationship between the law and the environment, with emphasis on land use and local government. More recently, there was a concern of studying in detail the issues related to the Nation State as a political and territorial construction.

In the 1990s, it was recognized in the American scientific community, the existence of an intersection between Law and Geography. In 1994, BLOMLEY ${ }^{2}$ encouraged discussion didactically, and demonstrated ways of interaction between subjects. In 1996, FORD ${ }^{3}$ organized major study of the law and the territorial limits in the Law Symposium in Stanford.

Since works of great expressiveness have been developed on social justice at various levels. In the 2000s two major books were published for the guid of interdisciplinary study, "The Legal Geographies Reader" and "Law and Geography", which deal with the interrelationship of geography in various branches of law. The relationship of these scientific fields is such that SOUZA SANTOS ${ }^{4}$ in the presentation

\footnotetext{
${ }^{1}$ OSOFSKY, H. M. A Law and Geography. Perspective on the New Haven School, p. 432.

${ }^{2}$ BLOMLEY, N. The Legal Geographies Reader, p. 3 - 5.

${ }^{3}$ FORD, R. T. Racial culture: A critique. Apud OSOFSKY, H. M.Obra citada, p.432.

${ }^{4}$ See Introduction. "Law and geography is one of the most promising "Law and fields". This book brings together some of the most representative scholarship of the nineties in this area (...)". SANTOS, B. S. The Legal Geographies Reader.
} 
of the book "The Legal Geographies Reader" pointed out that this is one of the most promising forms of interdisciplinarity of Law.

In this way, the geojurist ${ }^{5}$ FORD defends that in a legal context, space and places are not neutral definitions and that their structures influence social processes which in turn fed back into the spaces and locations. Thus, in the understanding of the teacher it is crucial to develop a geographical analysis of law to examine the relationship between geography, space and human rights.

One technique to address the geographical analysis of Law is to make the question "where?". When confronting a problem or a specific issue should be argued where the population is being tutored by a particular norm. Where the problems to be protected by the norm are. ${ }^{6}$ Thus, to understand the impact of the law on combating poverty, it is necessary to understand where labor relations are displaced, that is, what is the work experience that includes specific location to insert the new global economic order. With the unique ability to Anglo-Saxon synthesis, $\mathrm{AOKI}^{7}$ recommends that geography is about location, territory, land. Law, in turn, is about governance, regulation, and how to control this land.

Despite the great limitation to further our understanding of the interrelationship between law and geography before 1980, the Law School of Yale placed great emphasis on interdisciplinary studies that, in the case of geography, was held in conjunction with New Haven School. Such studies were initially based on three geographical constructs: global community, territorial units and centers of discussion.

Regarding the global community, the New Haven School sought to develop theory and tools for understanding the problems and processes that create international communities, and also about watching their disputes, through understanding of different points of view, in order to contribute to enhance the interactions between countries and interest groups globally, improving the international legal process. In studies of

\footnotetext{
5 We used the expression "geojurist" to identify professionals who develop interdisciplinary work between the geographical and the legal sciences.

6 "One simple way to conduct a geographical analysis of law is to ask the "where" question. When confronted with a problem or issue, ask such questions as: where are the relevant events taking place? Where are the relevant actors located? Where have they been? Where are they now? Where are they going? In examining the .where. question, what patterns or generalizations can we identify? As critical legal geographer Keith Aoki contends, to understand the impact of law on the poor, we need to ask where the poor and working people go, where are their spaces, what is their lived experience of place in the brave new world of the new world economic order.” AOKI, K. Law And Geography, p. 511

7 "Geography is about place, territory, land; law is about governance, regulation, and who is going to control this land.” AOKI, K. Idem, p. 515
} 
territorial units was considered that to understand the global community, and to be globally representative, it is necessary to have "fixed territorial bases" that will participate in the processes of global decisions. In other words, would be the establishment of a "local power". Finally, on the center of decisions, the concept of Arena $^{8}$, which refers to sports court previously mentioned, serves as the large key to the mechanism of decision making with overall legitimacy of multiscale acceptance.

There is consensus in the United States, that the geographical science has much to contribute to the law with the concepts of place, space and scale, offering for lawyers much more than the simple cartographic analysis to identify locations. And more: in spite of the slow development of "Law and Geography", he is now recognized as an important branch of interdisciplinary knowledge that even externalized their full potential, especially with the advent of geoprocessing tools.

Scientific demonstrations of such interrelation also been identified in Latin America. There are reports that the National University of Cordoba, Argentina, promoted on October 22, 1992 a day to discuss Law and Geographgy. This meeting called "Jornada sobre Derecho y Geography" aimed to examine, broadly, the relationship between Law and Geography in theory and in practice demonstrating the benefits that such a study would bring to the individual and social order in that country. ${ }^{9}$ As a conclusion of the journey, designs for the rational and harmonious promotion between Law and Geography ${ }^{10}$ were approved. Among them, to develop the study of the relationship between Law and Geography in universities that rely on the two courses, as well as before universities in Argentina and abroad, regarding the employment of knowledge and information as its practical application, providing support to scientists who engage in such interdisciplinary study.

In Brazil, there are scattered works, which include relevant epistemological differences of what would be the interdisciplinary study of Geography and Law. There were fundamental manifestation on the topic at the event "Diálogos Jurídicos e

\footnotetext{
${ }^{8}$ OSOFSKY, H. M. op. cit, p. 440.

${ }^{9}$ Issues of fundamental importance, divided into seven themes were developed, which are: (i) rationale de la relación interdisciplinaria derecho-geografía; (ii) derecho, geografía urbana y urbanismo; (iii) límites internacionales y geografia; (iv) la región geográfica frente al derecho; (v) el factor geográfico en la jurisprudencia de la Corte Internacional de Justicia; (vi) cuencas hídricas y derecho; e (vii) los factores geográficos en la Convención de las Naciones Unidas sobre el Derecho del Mar.

10 BELTRAMINO, J. C. M. Jornadas sobre derecho y geografía: rationale de la relación interdisciplinaria derecho-geografía ,p. 9-18.
} 
Filosóficos"11 or "Legal and Philosophical Dialogues" held in late April 2007, at the Faculty of Law in San Francisco Largo (USP), as part of the celebrations of 180 years of teaching of Law in Brazil. IRTI debated about what he termed "Geodireito" $(\text { Geolaw })^{12}$, that is, the relationship between the application of legal rules and their territoriality among states. ${ }^{13}$ FRAXE wrote on the application of "Geolaw" in the study of forest peoples, justifying the use of this expression in IRTI in order to admit a broad interpretation of this concept, referencing the "bond that exists between man and the land, so that offer viable solutions in the legal system for the ensuing conflicts". ${ }^{14}$

For CARNEIRO ${ }^{15}$, there is a spatial approach to normative Environmental Law, from the modern conception of Geography as applied science of solving social conflicts. The author seeks sustainable development and proper implementation of environmental legislation through the study of evaluative standard, aiming to build a very personal environmental awareness. Similar path was trodden by ALLEMAR. ${ }^{16}$

For GÓES ${ }^{17}$ the Geolaw should be understood as a scientific branch that investigates the relationship between Law and Geopolitics, that is, it would be the constitutionalization of Geopolitics, through a receiving international content coming from the geopolitic of the world's centers of power. ${ }^{18}$ In turn, ANTAS JR. ${ }^{19}$ exposes regarding the inseparability between actions and objects that can in part be understood through technical and rule. This inseparability is fundamental in the study between geography and law and their mutual implications.

\footnotetext{
${ }^{11}$ IRTI, N. Diálogos filosóficos com Natalino Irti: geodireito, tecnodireito e biodireito. Presentation held in April 27, 2007, at the Faculty of Law in San Francisco Largo (USP).

${ }^{12}$ Free translation for the expression "Geo-diritto".

${ }^{13}$ The panel consisted of three Professors, next to IRTI: Celso Lafer (Titular of Philosophy of Law), César Eduardo Silveira Vita Marchi (Titular of Roman Law) and Gilberto Bercovici (Associate of Economic Law).

${ }^{14}$ FRAXE, J. M. P. Geodireito entre os povos da floresta. Conselho Nacional de Pesquisa e PósGraduação em Direito - COMPEDI <http://www.conpedi.org/manaus/arquivos/anais/manaus/estado_dir_ povos_jaiza_maria_fraxe.pdf $>$, accessed on August 25, 2009.

${ }^{15}$ CARNEIRO, T. G. Epistemologia do direito ambiental: uma abordagem interdisciplinar da geografia e do direito normativo aplicado. Biblioteca Digital de Teses e Dissertações da Universidade Federal de Uberlândia. <http://www.bdtd.ufu.br//tde_busca/arquivo.php?codArquivo=1986>, accessed on August 25, 2009.

${ }^{16}$ ALLEMAR, A. A interdisciplinariedade entre o direito internacional e a Geografia como simbiose necessária para a análise e o planejamento ambiental. Centro de Investigação e Análise em Relações Internacionais - CIARE <http://www.ciari.org/opiniao/interdisciplinariedade_di_geografia.htm>, accessed on August 25, 2009.

${ }^{17}$ GÓES, G. S. O Geodireito e os centros mundiais de poder. Apresentação realizada no VII Encontro Nacional de Estudos Estratégicos, 06 a 08 de novembro de 2007, Gabinete de Segurança Institucional da Presidência da República, Brasília/DF.

${ }^{18}$ MELLO, C. D. A. Direito constitucional internacional, p. 5.

${ }^{19}$ ANTAS JR., Ricardo Mendes. Elementos para uma discussão epistemológica sobre a regulação no território, p. $81-86$.
} 
Some scientific currents, as the positive Law and the natural Geography, even when opposed have such discrepancy that border concomitant irrelevance. As geographical and legal dimensions are varied and are not always convergent, will spend up to establish some points on both scientific branches to produce a discourse of interdisciplinarity.

The geography that we will be guided is one in which its elements are arranged in formal Law. Such scientific branch seeks the "thingness" of spatial forms created by man and himself, neutrality, quantification as assumption of objectivity and scientific, studies of the similarities and regularities at the expense of differentiation, one analytical and idealistic society that eventually acquire a normative character. Thus, the geographical study in order to address this science as a "philosophy of technology",20 comes up. The approach of Law proposed here will be juspositivist as a set of principles and rules governing (effective) social life (sociology) of people in a given period (time) and location (space). It is the discipline of human conduct issued by the competent power legally established, so that it produces its effectiveness.

Therefore, it is assumed that an interdisciplinary approach is justified only between two scientific branches when placed in the same epistemological level. Thus, this paper will address the Geography and the Law from the perspective of duty be: Geography as philosophy of the techniques, the positive Law as the norm and the georeferencing as being suitable to be applied in the contemporary world technological impact. Within this conception, is need to check from where it is possible to speak of cartographic public politic in Brazil.

\section{The history of the National Cartographic System in view of the development of the electricity sector}

Despite Dom Pedro I has already shown great concern to gather information on the territory and the population, creating the Commission of Geographical Statistics $^{21}$ and seek to universalize the maps, through sale, at affordable prices, in the First Reign, ${ }^{22}$ one can assert that the Cartography started getting applied nature in Brazil

\footnotetext{
${ }^{20}$ SANTOS, M., Espaço e Método. P. 24. “(...)Therefore, geography can be considered a true philosophy of technology." (T.N.: Free translation from the original in Portuguese.)

${ }^{21}$ Commission created by Decree of November 25, 1829.

${ }^{22}$ Decree of June 14, 1830: Authorizes the government to increase and improve the lithographic garage of state property.
} 
in 1831, with the interest of Imperial Regency (1831-1840) to map the rivers of the Province of Minas Gerais. ${ }^{23}$ This reinforces the idea that mapping originates as support activity, and thereafter specialization of Engineering.

The Imperial Regency was not uninterested in developing the teaching of Geography. At least two standards, Decree 16, dated July 26, 1833, which created the chair of Geography in Piauí, and Decree 2 of 20 June, 1834, which created the chair of Geography in Goiás, demonstrates the regency interest in decentralizing this scientific branch. After all, if the people would have freedom of movement as envisaged in the 1824 Constitution, was handling the mapping through geographical knowledge, which would indicate where this right would be exercised. Finally, the creation of the Brazilian Historical Geographical Institute - IHGB, which occurred in 1838, an institution that would demonstrate great efficacy in the Second Reign.

With Dom Pedro II assuming the throne in 1840, IHGB seek to train scientists in Natural History (which involves Geology) and Geography. In 1842 the Section of Mineralogy, Geology, and Science was established in the Imperial Museum. ${ }^{24}$ In the following year, it established the Section for Agriculture, Mining, Colonization and Indigenous Civilization, in the Secretary of State for Business of the Empire. In 1859, Decree No. 2,335, of January 8, created the chair of Geography in Rio Grande do Sul, and in 1879, Decree No. 7.315, of June 14 approved the statutes of the Lisbon Geographical Society section in Brazil. This was the Emperor's attempt to set up a national identity in order to give unity to the country, using geography to achieve this goal.

In the ongoing consolidation of Geosciences in Second Reign, the American geologist Orville Adelbert Derby (1851-1915) played a fundamental role in Brazil. Arising from Cornell University, Derby finished his doctorate in June 1874, under the title "On the Carboniferous Braquiopoda of Itaituba, Rio Tapajós." In 1876, Derby was contracted to the section of the National Museum of Mineralogy. At that time, there was interdisciplinary understanding of geographical science, while engineering specialty. As an example, Decree 3001 of October 9, 1880, established the requirements that should satisfy domestic or foreign Civil Engineers, geographers, surveyors and trained graduates in mathematics, to be able to perform jobs in

\footnotetext{
${ }^{23}$ Decree of August 12, 1831: orders that the Province of Minas Gerais have two engineers in charge of conducting a survey of all maps of roads and navigable rivers.

${ }^{24}$ The Royal Museum in Rio de Janeiro was created in 1818.
} 
commissions. With the contribution of Derby, the Geographical and Geological Commission of São Paulo was founded through the Provincial Law No. 9 of 27 March $1886 . .^{25}$

With the abolition of slavery in 1888 and the advent of the Republic in 1889 , Brazil had the regulation of notary service, called at the time "geographic". The conception of geography was transformed under the Republic, which thus passed as it was Cartography, being a specialization of the engineering activity. Worth noting that this activity would be under the responsibility of military ministry - of War. The justification of this Decree was drafted by Rui Barbosa, who grounded before the so President General Deodoro da Fonseca, the creation of the Geographic Service in order to satisfy an economic and legal craving.

Generalissimo. - The institution devoted to the project that we have the honor to submit to you, is the most advanced stage of contemporary ideas regarding land ownership, the most beneficial of all arrangements for their development and multiplication in today's societies. Its aim is to establish an effective system for estate advertising and commercialize circulation of securities relating to dominion over the earth.

In the words of an Italian publicist, the ideal of economists and jurists would be constitute public records, where the demonstration was easy land ownership and expeditious, as well as research on the actual duties incident to property ownership, and gather into one the various advertising agencies existing between us, namely, record, register, hipotheca, and transcripts. Only in this way would constitute a kind of civil status of property ownership, corresponding to the civil status of individuals, and a good system for the mobilization of stable property, without which it will be unavailing to expect perfect organization of the territorial claim. ${ }^{26}$

\footnotetext{
${ }^{25}$ Currently designated Instituto Geológico de São Paulo (Geological Institute of São Paulo).

${ }^{26}$ Decree No. 451-A, May 31, 1890: Reorganizes the Observatory of Rio de Janeiro, creating geographic service, which will be annexed thereto, and transfers it to the War Office. (T.N.: Free translation from the original in Portuguese.)
} 
Even in the Old Republic, the result of a report about the Canudos war of 1896, in Bahia, Euclides da Cunha published "Backlands: The Canudos Campaign", a work of great and consistent geoscientific significance, after receiving the comments of Derby and the Geographer engineer Teodoro Sampaio. Decree No. 908-A, November 13, 1902, ${ }^{27}$ conferred the title of Geographer engineer to students of the Polytechnic School of the Federal Capital and the School of Mines of Ouro Preto. In 1906 was created the Ministry of Agricultural Affairs, Trade and Industry, under Decree No. 1606, of December 29, 1906. The Ministry was in charge of sectors such as agronomy, indigenous issues, matters relating to flora and fauna, astronomy, meteorology, cartography, irrigation and drainage, mining and legislating, explorations and geological service, metallurgical establishments and schools of mines, among other. Mining and Geology became professions, allowing to create the base, though incipient, of hydrocarbons and mineral energy exploitation in Brazil, such as uranium, thorium, among others. Thus, in 1910 the Decree No. 8359, of November 9, reorganized the Geological and Mineralogical Service of Brazil. The following years were of constant capitalization of the Military Geographic Service, ${ }^{28}$ a fact which lasted throughout Old Republic.

Only during the govern of Getúlio Vargas (1930 - 1945) there was a concern to reorganize the national institutions in general and segregate the functions of Geology and Geography of Engineering in particular. This initiative culminated in the creation, among other agencies, of:

(i) Regulation of Geographical Service, which came to be delegated to the Army, pursuant to Decree No. 21883 of September 29, 1932;

(ii) Geological and Mineralogical Institute of Brazil; ${ }^{29}$ Federal Biological Institute; Institute of Meteorology, Hydrometric and Agricultural Ecology; and Institute of Chemistry, all by virtue of Decree No. 22508 of February 27, 1933;

\footnotetext{
${ }^{27}$ Decree No. 908-A, November 13, 1902: Sets the collation of the title of geographer engineer students of the Polytechnic School of the Federal Capital and the School of Mines of Ouro Preto. (T.N.: Free translation from the original in Portuguese.)

${ }^{28}$ For more information, particularly about the financial amounts contributed, see Decree 12.945, of April 3, 1918; Decree 13.481 of February 19, 1919; Decree 15.125, of November 18, 1921; and Decree 4.367, of November 18, 1921.

${ }^{29}$ Replacing the Geological and Mineralogical.
} 
(iii) The Water Code, created by Decree-Law No. 24643 of July 10, 1934, passed just a week before the promulgation of the Constitution of the Republic of 1934, of July 16, 1934, which in turn be enunciated incumbent upon the Union to legislate on hydropower;

(iv) National Department of Mineral Production - DNPM, under the Ministry of Agriculture; by virtue of Decree No. 24648 of July 10, 1934;

(v) National Institute of Statistics - INE, in accordance of Decree No. 24609 of July 6, 1934. Worth noting that the census service, demographic and economic aspects would be under the Ministry of Justice and Internal Affairs (Article 3, Paragraph 2, I).

Thus, Brazil has specialized and imposed the need for new instruments of public land management in general and in particular of Geosciences. With the advent of the New State and the Federal Constitution of 1937, the first time it tries to identify regionalidades through municipal groupings for installation, operation and management of public utilities. ${ }^{30}$ This Magna Carta approached geography of economic and social issues, forming part of the set of tasks of the National Economic Council.

The Constitution of 1937 made possible the creation of the Brazilian Council of Geography, established under Decree 1527, 1937, and guided by an international and a national logic. There was the interest that Brazil was part of the International Geographical Union and the need to establish a body of cooperative Brazilian geographic activities.

This legal device allowed the president Getúlio Vargas use the international and national precepts to create the Brazilian Institute of Geography and Statistics -

\footnotetext{
${ }^{30}$ Article 29. Municipalities of the same region can be grouped for the installation, operation and management of public utilities. The group thus constituted shall be provided with limited legal personality to its purposes. Sole Paragraph - It is up to the states regulate the conditions under which such groups can be constituted as well as the form of their administration. (T.N.: Free translation from the original in Portuguese.)
} 
IBGE ${ }^{31}$ on January 26, 1938. Through of Decree-Law No 311, of 02 March 1938, also known as the "Law of Geographic New State", occurred the creation of politic of regional territorial division to resolve conflicts and use as a tool for handling statistical data. Concepts that were mixed geographical and legal criteria in order to harmonize the federal powers through territorial division.

But IBGE was created, the first census was already scheduled to take place in 1940, under Decree-Law No. 237, February 2, 1938, and there was the legal provision that internal territorial dynamics would be improved. In 1939 The President Vargas also would create the National Board of Water and Power - CNAEE.

However, the country entered the Second World War in the early 1940s and initiate a series of institutional difficulties. There was a massive energy rationing in 1942. Meanwhile, the regular session of Geography and Statistics National Councils ceased to be held in $1943^{32}$ and in $1944 .{ }^{33}$ Service Geography and Cartography IBGE only would be created by Decree-Law n 6828, August 25, 1944.

The Federal Constitution of 1946 can be considered a period of transformation of the national infrastructure, given the signs of direct state action in the capital-intensive, especially the energy sector. It is the first Magna Carta which expressly states the Union's competence to legislate on energy, including electricity, as well as underground riches. ${ }^{34}$ To provide competence to legislate on electricity, the Federal Constitution of 1946 emancipated the concept of electricity from water use, legally recognizing the existence of other technological matrices.

In the regime of President Dutra, the rules for standardizing the Brazilian cartography were fixed. Decree-Law No. 9210 of 29 April 1946 authorized some institutions with competence required to produce charts, namely: the National Council of Geography, the Brazilian Institute of Geography and Statistics and Geographical Service of the Army. For this, the technical standards relating to the preparation of hydrographic charts were made by the Board of Navigation of the Navy, with those

\footnotetext{
${ }^{31}$ Decree-Law No. 218 of January 26, 1938: Renames the National Institute of Statistics and the Brazilian Council of Geography.

${ }^{32}$ Decree-Law No. 5.635, of June 30, 1943.

${ }^{33}$ Decree-Law No. 6.588, of June 14, 1944.

${ }^{34}$ Article 5 - The Union shall have the power to:

(...)

$\mathrm{XV}$ - legislate on:

(...)

l) subsoil, mining, metallurgy, water, electricity, forests, hunting and fishing;

(...)
} 
aeronautical under the responsibility of the Aeronautics Directory of Routes. Finally, technical standards relating to geological and climatic charts were, respectively, under the responsibility of Geology and Mineralogy Division and the Bureau of Meteorology of the Ministry of Agriculture. Law No. 960 of December 8, 1949, disciplined, for the first time, the activities of aerial survey in Brazil, setting competence to the Union and some private companies.

According to IBGE, ${ }^{35}$ the economic and social changes in the 1950 s and the first half of 1960 imposed the review of the regional divisions, using as a base characteristics of homogeneity of production. Geography produced by IBGE moved away from the initial purpose of revitalizing municipalities, or perform a new territorial division, so that started to work with a focus on socio-economic aspects. The censuses of $1950^{36}$ and 1960 occurred within the national priorities of those moments. Under the legal perpective, it was not a period of major methodological innovations or modification of functions of IBGE, but steady appreciation of its attributions and continuous institutional improvement.

The major innovations have returned with a new regime of exception. The military regime installed in 1964 had as one of its most forceful speeches the need to centralize the planning of the country, with important impact in the cartographic and energy sector. In 1967, with the Constitution bestowed, start up concerns about national development $^{37}$ (Article 8) and the National Congress allowed to dispose about national and regional plans and programs (Article 46). ${ }^{38}$ Continuous act, the Constitution bestowed innovated by employing the concept of region to institutionalize multi-annual allocations for the implementation of plans for developing less-developed regions of the country (Article 65) ${ }^{39}$ and to establish metropolitan regions, composed of municipalities

\footnotetext{
${ }^{35}$ IBGE, Methodological Notes on the 2000 Census.

${ }^{36}$ In 1950, the Political Map of Brazil recorded the extinction of the Territories of Ponta-Porã and Iguaçu, by the Constitution of 1946. According to the Census, Brazil had approximately 52 million people in 1.889 municipalities.

${ }^{37}$ Article 8. The Union has the competence to: (...) XIII - establish and implement regional development plans; (...).

${ }^{38}$ Article 46. To the National Congress, with the sanction of the President of the Republic, it is provided by law, on all matters of Union competence, especially: (...) III - national and regional plans and programs, and pluriannual budgets; (...).

${ }^{39}$ Article 65 . The annual budget will be divided into current and capital and shall necessarily include the expenses and revenues related to all Powers, agencies and funds, both the Direct Administration as the Indirect excluded only those entities that do not receive subsidies or transfers to the account budget. (...) Paragraph 6 - The budget shall set forth pluriannual allocations for the implementation of plans for the recovery of the less developed regions of the country.
} 
that made the same socioeconomic community even with distinct administrative linkage. ${ }^{40}$

Several initiatives have been taken to plan Brazil, in a centralized and determinative way. As an example of this historical moment with some converging to the scope of the present work initiatives, the consortium Canambra Engineering Consultants Limited (Canada - America - Brazil) was funded by the World Bank, that: (i) substantiate energy planning in Brazil; (ii) enabled the raising of the hydroelectric potential; and (iii) created conditions to develop the country's economy through the Economic Action Program of the Government (PAEG) from 1964 to 1966 and the Strategic Development Plan (SDP) from 1968 to 1970. It was the establishment of new methodologies planning based on long term expansion. Soon, Canambra made possible the existence of a centralized planning, in order to create conditions for interconnection of systems and install large reservoirs under the operation of Eletrobras.

Besides the energy area, the rapprochement with the United States also occurred in the cartographic area. The biennium 1966/1967, the President Castelo Branco established working group to define the Guidelines and Bases of National Cartographic Politics, which culminated in Brazil - United States Agreement for Cartographic Services (CMEABEUSC). Despite the records of legal acts that supported the group, the literature on this subject is scarce because the agreement had strong military appeal. The justification for this is that the economic and social development of the country was linked to national security. Thus, in February 1967 were published two Decree Laws, which gave new parameter to the National Geography and Cartography.

Decree-Law No. 161 of February 13, 1967: Authorized the establishment of the Brazilian Institute of Geography and Statistics Foudation - IBGE Foundation; the National Plan of Statistics; and the National Plan for Geography and Land Cartography; and

(ii) Decree-Law No. 243 of February 28, 1967: defined the Guidelines and Bases of Brazilian Cartography, creating a unique system, called the National Cartographic System - SCN, subject to the

\footnotetext{
40 Article 157. The economic order is intended to promote social justice, based on the following principles: (...) Paragraph 10 - The Union may, by means of supplementary law, establish metropolitan regions, formed by the grouping of adjacent municipalities that, regardless of their administrative linking, integrate the same socio-economic community for the realization of common interest.
} 
discipline of plans and normative instruments; and Cartography Commission (headdress), an agency of the IBGE tasked with coordinating the implementation of the National Cartographic Politics, consisting of a representative of the Ministry of Marine, the War, Aeronautics, Agriculture, Mines and Energy and the National Association of Aerophotogrametry.

Thus, the representation of Brazilian territorial space would be made by charts, drawn selectively and progressively, depending on term priorities, according to the land, aeronautical and nautical cartographic standards. In turn, systematic cartographic surveys must be supported on a single plane-altimetric system, geodetic control points, materialized on the ground by means of landmarks, pillars and signs, made under the law.

This system allowed considerable cartographic mapping of the country, contributing significantly in infrastructure projects such as the Itaipu and the Tucuruí Hydroelectrica, the Rio-Niteroi Bridge, the Trans-Amazon Highway, among others. It can be stated that, concomitant with the "Economic Miracle", Brazil had the peak of its cartographic production due to modernization of equipment and production processes.

In 1969, a new framework was released by IBGE, composed of five major regions existing today: ${ }^{41}$ North, Northeast, Southeast, South and Center-West. The framework of regional divisions in intermediate level was only developed in the 1970s and published in 1976, totaling 86 mesoregions homogeneous. Important to emphasize Decree 89817 of 20 June 1984, which established the Regulatory Instructions of the Technical Standards of the National Cartography to create, after approval of the COCAR, the Brazilian Compilation of Cartographic Standards, which was part of a fundamental Geographical coded system.

This model of Geography and Cartography, ${ }^{42}$ based on the strong centralization of planning, with a large cartographic production, would impose new paradigms after the Constitution of 1988: do planning with democracy.

\footnotetext{
${ }^{41}$ Subsequent changes resulted from the creation of the State of Mato Grosso do Sul (1979), incorporated into the Center-West Region and the State of Tocantins (1988), incorporated in the Northern Region.

${ }^{42}$ In 1978 there was the creation of the Plan of Stimulation of Cartography - PDC/78 to intensify the Brazilian systematic mapping, aiming at full coverage of the territory on the scale of 1:250.000 and the increased coverage on scale 1:100.000 (in the Central-West and Northeast regions and part of the
} 
Currently for Geosciences Union competences to organize and maintain the official statistical services, geography, geology and cartography nationwide are exposed in Article 21, item XV of the Federal Constitution (FC) 1988, which still reserve as private of the Union to legislate on statistical, cartographic and geological system (Article 22, XVIII, CF) and provides coordinate its action in the same geo-economic complex to reduce regional inequalities (Article 43, CF). These are the basis to justify state action in geotechnology.

For this institutional realignment, was created after several instabilities in achieving the acts of COCAR, the National Commission of Cartography - CONCAR under the Ministry of Planning, Budget and Management, pursuant to Decree of 10 May 2000 and Decree 4781 of 16 July 2003. It was the adequacy of cartographic standards after fifteen years of re-democratization of Brazil, still timid practical results, despite its strategic plan to be effective since 2005. Its main initiative is the viability of the

National Spatial Data Infrastructure - NSDI that established by Decree No. 6666 of November 27, 2008, is defined as an integrated set of technologies; politics; mechanisms and procedures for coordination and monitoring; standards and agreements necessary to facilitate and organize the generation, storage, access, sharing, dissemination and use of geospatial data from federal, state, county and municipal origin.

\section{For an epistemology of Geolaw produced in democratic period:. The case of electricity}

The Geolaw, understood as a legal branch that studies the spatial criterion of public politics, will have to be deepened in the electricity sector to converge sectoral regulation with constitutional matrix of cartographic and geographic national system. Its justification is endorsed by the competence of the Union to organize and maintain the official statistical services, geography, geology and cartography nationwide (Article 21, $\mathrm{XV}, \mathrm{CF}$ ), with private legislate on statistical, cartographic and geological system (Article $22 \mathrm{XVIII} \mathrm{CF}$ ) and being allowed to articulate its action in the same geoeconomic complex to reduce regional inequalities (Article 43, CF).

Southeast and Northern), 1:50.000 (in the South and part of the Southeast and Northeast) and in scale 1:25.000 (in state capitals). (Source: Concar) 
The Geolaw identifies the Brazilian Institute of Geography and Statistics IBGE as the regulator of this system, and the Cartographer, the Geographer and the Surveyor as the technicians that will work in sectoral public politics. ${ }^{43}$ There are several public politics at the federal level that seek to intensify the use of geotechnologies. There are at least three initiatives that deserve attention, in spite of being in different levels of enhancement of public politic:

a) Law No. 10267 of 2001, which made obligatory georeferencing, to the dismemberment, split or rememberment of rural properties. Land grabbing, secular practice in Brazil, will find an effective way to be tackled: by latitude and longitude, embodied in law, which gave the aerometric images force of law to the real case.

b) The Provisional Measure No. 547 of 11 October 2011 which amended the City Statute, the Law of Installment Land, and the Law of the National System of Civil Defense - SINDEC to establish a national register of municipalities with areas suitable the occurrence of large landslides or impact related geological processes, with the aim of forcing municipalities to formulate mapping containing the areas with occurrence of large landslides or impact related to geological processes; well as to create geotechnical suitability charts to urbanization, in the definition of urban planning guidelines to ensure the safety of the new installment of urban land.

c) The current proposal for the Forest Code, which includes the use of georeferencing to establish a spatial criterion in the Legal Reserve, the Program of Environmental Regularization - PRA, the Plan for Sustainable Procurement - PSS, the Quota of Forest Reserve CRA and the Institute of Forest mitigation. Regardless of

\footnotetext{
${ }^{43}$ Cartography and Geography are distinct professions, but correlated, and so were preserved under the institutional principle. It is not up to the geographer make charts and maps, but interpret them in conjunction with other variables, which may be economic, social, etc... Similarly, the lawyer is not competent to make laws, this challenge entrusted to the legislature. But it is up to lawyers to interpret them, together with other sources of law.
} 
ideological choice of the proposal, who reads the report of Rep. Aldo Rebelo quickly notes the geographic focus given to the justification, when mentioned Josué de Castro, in his work The Geography of Hunger, while a Malthusian counterpoint to solve many environmental problems.

The energy sector has an important example of the application of this interdisciplinarity. Under the scientific perspective, this segment of society used geography as a branch that aligned technology and development as tools to control nature.

Considered in the historical and geographical region, the electric energy in Brazil is one of the chapters of national development at which most reveals the collective ability to leverage technological advances to dominate nature. At first, and in the absence of coal, confined to the South, and in precarious holding, and after disarticulated, without, however, reach large initial hopes, it was used the water courses in measure, which was sufficient to meet the needs of lighting and transport. From the twenties, it becomes easier to use hydraulic power. ${ }^{44}$

Obeying this trend, the National Electric Energy Agency - ANEEL opened the Public Consultation No 002/2012 to progressively enhance the use of Geographic Information System - GIS to regulate and supervise the services under its jurisdiction. In establishing the Equity Control Manual of the Electric Sector - MCPSE (Normative Resolution 367/09), which imposes new systematic control of network assets in immobilized service; and the Geographic Database of the Distributor - BDGD established in Revision 1 of the Procedures for Electric Energy Distribution in the National Electric System - PRODIST (Normative Resolution 395/09), which requires distribution companies to provide annually the complete record of georeferenced lines and distribution networks, georeferencing becomes a reality to be perfected as an instrument of public politic in the electricity sector.

${ }^{44}$ EXÉRCITO. Energia elétrica no Brasil (da primeira lâmpada à Eletrobras). Rio de Janeiro: Biblioteca do Exército, 1977. p. 46. 
As defined in Module 6, the BDGD must be sent annually by the distributors to ANEEL, by January 31 of each year, with the data referenced in the preceding December 31. In this context, the data transmission started in 2011 and already in January 2012 the second annual shipment data for ANEEL occurs. Important to remember that there is, in the Indicative ANEEL Regulatory Agenda for the 20122013 Biennium, the realization of the activity "Reviewing regulations on Geographic Information Regulatory System - GIS-R (Modules 2:06 of Distribution Procedures PRODIST)".

The importance of georeferencing is to enhance the reliability and traceability of information assets for Periodic Tariff Review process, allowing to know the quantity of total assets, by type, by date and by location. First step towards the implementation of the smart grid, can be glimpsed in the near future, that the SIG has a central role in energy planning in general, in the regulation and supervision, as well as in the management of specific dealerships.

It is not difficult to realize that it is not enough to create a Regulatory GIS without identifying the legal and geoscientific support. The interdisciplinary studies between Geography and Law became indispensable in the 21 st century. There is an ongoing technological revolution in the world. By combining the advent of the internet, with satellite technology, cartography and remote sensing as computational projects, and the ability of current data management software, Geography is qualified as a scientific branch that produces spatial analysis. In turn, the Law regulates public politics for this purpose.

Logo, Aneel itself indicates the need to establish rules for the coexistence of different legal regimes, a fact that goes back to the concept that justified the creation of IBGE in 1938, of having a great planning of the Brazilian space with different legal systems of matrices but live together harmoniously. It is the metaphor of the sports field in practice.

Despite advances in the recognition of GIS as a public politic in the energy sector, there will not be greater insights on this front if it does not notice the IBGE as regulator of the Brazilian Geodesic System, a fact that imposes forms of interlocucção with Aneel. The resolutions of the IBGE, including: (i) RPR No 1, 2005, featuring the Brazilian Geodetic System; (ii) No RPR. 001, 2008, which standardizes the geodesic marks; (iii) RPR No 22, 1983, which specifies the General Standards for Geodetic Surveys; (iv) RPR No 5, 1993, which specifies the General Standards for surveys; and 
(v) RPR No 23, 1989, establishing parameters for processing of geodetic systems, culminating in a true legal system that must be attended by professionals who study the regulatory aspects of the energy sector, under penalty of being outside in public management revolution that the sector will throughout the twenty-first century.

Presumably, in the near future, the SIG has a central role in energy planning in general and in the expansion of alternative energy sources in Brazil in particular. It is not difficult to see that the Geolaw as a legal branch that studies the spatial allocation of public politics will have to be deepened to create a wind SIG, like many countries already have including web ambience and Brazil still not made it possible, as well as a solar SIG in order to account for the location and load boards allocated on top of buildings in Brazilian cities. These guidelines will bring themselves legal relationships that will need discern the rights and obligations of the consumer units, which will also be generators, natural consequence of the development of the smart grid. It is the future that lies ahead and brings new challenges for public politic.

If George Orwell was right when he wrote in the book "1984" that "the possibility of enforcing not only complete obedience to the will of the State, but complete uniformity of opinion on all subjects, now existed for the first time", ${ }^{4}$ geotechnologies will have a central role to identify, online form, larceny, fraud, delinquencies, infrastructure sharing, need for pruning trees, among numerous other effects.

\section{Conclusion}

It is common in geoscience circles find heated debates about what should be the actual size of state intervention in this segment of society. The dialectic between technological development and public interest is a constant in the history of civilizations, and the state the most effective tool to achieve the goal of intervention in individual and collective interests.

There are various forms of State intervention in geotechnologies to build a sectoral public politic. Central to this initiative is the creation of the Brazilian Geographic Information System through the establishment of the National Spatial Data Infrastructure - NSDI, which certainly will give huge advances with regard to

${ }^{45}$ ORWELL, George. 1984. Tradução de Wilson Velloso. 23. ed. São Paulo: Editora Nacional, 1996. P. 154. 
identifying the public interest in the Brazilian geoscientific system. Among the needs there are those to accompany the changeability high technology; provide mechanisms for the exchange of spatial data from diferent technology platforms; create national standard of cartographic methodology; develop GIS tool at low cost; intellectually protect inventions; universalize the geoscience tools; among others.

Therefore, the concept of regulation of the electricity sector gains a fundamental force in the systematization of the use of geotechnologies. The initiatives undertaken by the National Electric Energy Agency - ANEEL, to open public consultation to progressively enhance the use of Geographic Information System - GIS in the regulation and inspection services under its jurisdiction is commendable. However, it should be respected the secular construction of cartography and geography held in Brazil, harmonizing the Manual Assets Control of the Electric Sector - MCPSE, Geographic Database of the Distributor - BDGD and Procedures for Electric Energy Distribution in the National Electric System - PRODIST, the regulations issued by the IBGE, as well as adhere to the assumptions of the electricity sector standards of Concar, by INDE, and the municipal master plans and set geo-economic complex, as is the case, for example, of watersheds, metropolitan áreas, among others.

\section{References}

ALLEMAR, A. A interdisciplinariedade entre o direito internacional e a Geografia como simbiose necessária para a análise e o planejamento ambiental. Centro de Investigação e Análise em Relações Internacionais - CIARE <http://www.ciari.org/opiniao/interdisciplinariedade_di_geografia.htm>, acessado em 25 de agosto de 2009.

ANTAS JR., Ricardo Mendes. Território e regulação: espaço geográfico, fonte material e não-formal do direito. São Paulo: Humanitas: Fapesp, 2005.

AOKI, Keith. Law And Geography. Santa Clara Journal Of International Law, 20 de julho de 2007.

BELTRAMINO, Juan Carlos M. Jornadas sobre derecho y geografía: rationale de la relación interdisciplinaria derecho-geografía. Biblioteca de La Facultad de Derecho y Cs. Sociales, 341.2 J 36273, Argentina, Manantial, 1994. 
BLOMLEY, Nicholas; DELANEY, David e FORD, Richard T. The Legal Geographies Reader. Blackwell Publishers, 2001.

CARNEIRO, Tony Geraldo. Epistemologia do direito ambiental: uma abordagem interdisciplinar da geografia e do direito normativo aplicado. Biblioteca Digital de Teses e Dissertações da Universidade Federal de Uberlândia. <http://www.bdtd.ufu.br//tde_busca/arquivo.php?codArquivo=1986>, acessado em 25 de agosto de 2009.

EXÉRCITO. Energia elétrica no Brasil (da primeira lâmpada à Eletrobras). Rio de Janeiro: Biblioteca do Exército, 1977.

FRAXE, J. M. P. Geodireito entre os povos da floresta. Conselho Nacional de Pesquisa e Pós-Graduação em Direito _ <http://www.conpedi.org/manaus/arquivos/anais/manaus/estado_dir_povos_jaiza_maria _fraxe.pdf>, acessado em 25 de agosto de 2009.

GÓES, Guilherme Sandoval. $O$ Geodireito e os centros mundiais de poder. Apresentação realizada no VII Encontro Nacional de Estudos Estratégicos, 06 a 08 de novembro de 2007, Gabinete de Segurança Institucional da Presidência da República, Brasília/DF. Encontrado em https://sistema.planalto.gov.br

IBGE. Notas Metodológicas ao Censo 2000. www.ibge.concar.gov.br. Extraído em 02 de agosto de 2010.

IRTI, Natalino. Norma e luoghi, Problemi di geo-diritto. Roma-Bari: Laterza, 2001.

ORWELL, George. 1984. Tradução de Wilson Velloso. 23. ed. São Paulo: Editora Nacional, 1996.

OSOFSKY, Hary. M. A Law and Geography. Perspective on the New Haven School. The Yale Journal of International Law. Ed. Forthcoming, 2007.

SANCHES, Luiz Antonio Ugeda. Curso de direito da energia - Tomo I. São Paulo: Instituto Geodireito Editora, 2011.

SANCHES, Luiz Antonio Ugeda. Geodireito e a divisão do trabalho. 2009. Dissertação (Mestrado em Direito) - PUC/SP, São Paulo.

SANCHES, Luiz Antonio Ugeda. O geodireito enquanto identificação do conteúdo da geografia no direito: o caso do setor de energia como propulsor de desenvolvimento regional. 2010. Dissertação (Mestrado em Geografia) - PUC/SP, São Paulo.

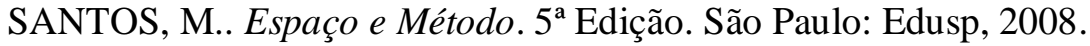

